\title{
Chinese Postgraduate Students' Perspectives on Developing Critical Thinking on an UK Education Masters
}

\author{
Labake Fakunle ${ }^{1}$, Pete Allison ${ }^{1, *} \&$ Ken Fordyce ${ }^{1}$ \\ ${ }^{1}$ Graduate School of Education and Sport, The University of Edinburgh, Holyrood Road, Edinburgh, Scotland \\ *Correspondence: Room 4.13, St Leonard's Land ISPEHS, Graduate School of Education and Sport, The University \\ of Edinburgh, Holyrood Road, Edinburgh, EH8 8AQ, Scotland. Tel: 44-131-651-6001 E-mail: \\ Peter.Allison@ed.ac.uk
}

Received: November 20, 2015 Accepted: December 23, $2015 \quad$ Online Published: February 22, 2016

doi: $10.5430 /$ jct.v5n $1 \mathrm{p} 27$

URL: http://dx.doi.org/10.5430/jct.v5n1p27

\begin{abstract}
Statistics on enrolment of international students in higher education, and studies on limitations of their adaptation to other (usually Western) cultural and learning norms dominate literature. There is much less emphasis on a specific aspect of the student experience. This study examined Chinese postgraduate students' perspectives on how they develop critical thinking during a one year postgraduate programme in Education. Semi-structured interviews conducted with six Chinese students illuminate key occurrences over the study period which impacted their learning. Findings suggest that participants needed to adjust to the concept of critical thinking and the expected level of critical thinking on their programme. A key factor identified in the study suggests that a trigger event: coursework feedback, affected how the participants develop critical thinking. The study concludes with suggestions for timely pedagogical support to enhance the learning experiences of Chinese students who encounter unfamiliar academic requirements during their study abroad.
\end{abstract}

Keywords: Chinese students; postgraduate education; critical thinking; adaptation; internationalisation

\section{Introduction}

In just over a decade, the number of Chinese students in UK HEIs increased by $146 \%$; from 35,740 students in $2002 / 03$ (Shi, 2006) to 87,895 students in 2013/14 (HESA, 2015). Also, for the last three academic sessions $(2011 / 12$ - 2013/14), 1 in every 4 (26\%,28\% and 28\% respectively) non-EU student came from China. HESA (2015) published data show that first year student enrolment of Chinese students in UK HEIs in the academic year 2013/14 exceed total student numbers from all European Union countries (see Figure 1).

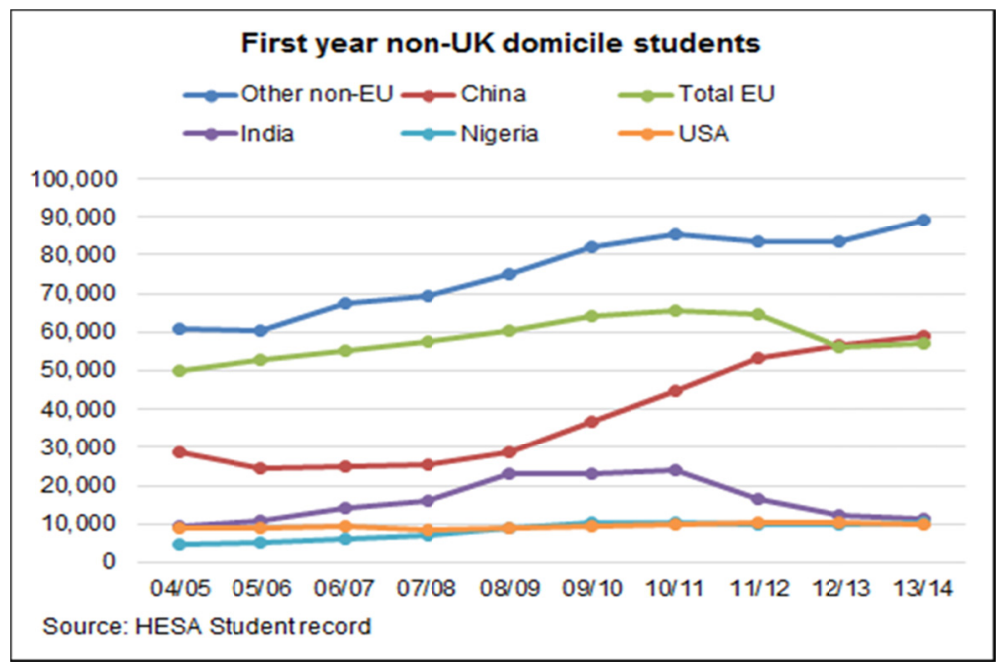

Figure 1. First Year Non-UK Domicile Students in UK HEI's 2004/05 - 2013/14

Source HESA 2015 
There is little doubt that the huge representation of Chinese students in UK HEIs motivate wide-ranging research efforts to examine their psychological, sociological and educational adaptation to the UK academic environment (Spencer-Oatey \& Xiong, 2006; Zhou \& Todman, 2009). Fairly recent investigation examine trends in their educational attainment in the UK (Iannelli \& Huang, 2013). However, the vast majority of research on Chinese students learning experience in the UK focuses mainly on interculturality (Gill, 2007; Schweisfurth \& Gu, 2009) with emphasis on the dissonance between the academic culture in East Asian countries and in the UK (Durkin, 2008; Tian \& Low, 2011; Wu \& Hammond, 2011). As yet, there has been very limited attention given to the specific area of academic adjustment of postgraduate students.

For political and economic reasons, the UK, at both national and regional levels shows a high level interest in maintaining education links with China. At the 6th UK-China Education Summit in London in 2011, which involved consultation and collaboration between UK and Chinese Education ministers, 19 UK Vice Chancellors, and 12 Chinese university presidents, the three main themes on the agenda were; Joint programmes, research collaboration and student mobility (BIS, 2011). Scotland, a country within the UK with devolved education powers also embarked on its 'China Plan' in 2006. The China plan has been taken forward in a 5 year strategic plan to further strengthen economic and education collaboration between the two countries with aims to increase the number of students from China and Hong Kong Special Administrative Region studying in Scottish Universities as a percentage of their total population in the UK. Overall, the UK is seeing growing numbers of students from China. This could be conceived as a result of the growing relationship between the two countries. As acknowledged at the UK-China Higher Education Roundtable, China's second largest research collaborator is the UK (British Council, 2014). Despite this, Ms Stern, Director of the UK Higher Education International Unit, cites "strong differences which persist between the two education systems" in the British Council UK-China Higher Education Roundtable Report (2014, p. 2).

While policy documents from Scottish Government (e.g., the Five Year Strategy for Engagement between Scotland and the People's Republic of China) indicate that students from China and Hong Kong SAR are grouped together for strategic economic and educational alliances, it is important to point out that, in agreement with many researchers, it is probably inappropriate to consider students from China as a homogenous group. China is part of the East Asian geographic region with differing political, philosophical, social cultural and economic characteristics (Burke, Keating, Vickers, Fearnside, \& Bateman, 2009), but a common Confucian heritage which is in contrast to Western Socratic traditions (Durkin, 2008). Nonetheless, Wang (2013) suggests that the Chinese learner of the $21^{\text {st }}$ century will be influenced by both Western and Eastern education traditions. It will be interesting to see how forces of globalisation and internationalisation with increasing appetite for research collaboration, and unimpeded student mobility between countries may yet have an impact on hitherto firmly entrenched contradictory philosophical positioning between the East and the West.

At present, language differences clearly distinguish the East and the West. For educational purposes, this issue is moderated by language testing to further assess the ability of international students to study in a foreign country. For example, the International English Language Testing System (IELTS) is a widely recognised test of English which is accepted by more than 9,000 organisations in over 145 countries, including most universities in Australia, Canada, New Zealand and the UK. Proficiency in English language is a key influence in the transition of postgraduate Chinese students in the UK (Zhou \& Todman, 2009). This suggests that the ability to read, write, and speak English, which is assessed by IELTS is a logical prerequisite for study in a country where the language of instruction is English. But research conducted at universities in Australia, and the UK shows that high IELTS results do not necessarily correlate with high academic attainment (Bayliss \& Ingram, 2006; Edwards \& Ran, 2006). Many studies point to the difficulties Chinese students encounter when faced with the academic requirements in the UK, especially at Master's level of study, and in particular, how they are seen not to demonstrate critical thinking skills (Tian \& Low, 2011; Wu \& Hammond, 2011). With available empirical evidence, it can be argued that, IELTS is a language test which cannot conclusively test the ability to cope with the demands of learning new concepts in a different academic environment.

Developing critical thinking in students is a key aim of higher education in Western countries (Barnett, 1997), and an important criterion for grading student writing in the UK (Brown, 2008; Elander, Harrington, Norton, Robinson, \& Reddy, 2006). The importance of criticality expected for Masters-level of study is explicated in pertinent qualification framework (see Table 1). 
Table 1. Qualification Frameworks for Masters Level of Study: International (EQF, FQ-EHEA), National (SCQF), and Institutional (School of Education). For More Specific Information on SCQF See http://scqf.org.uk/

\begin{tabular}{|c|c|c|}
\hline EQF Level 7 & SCQF Level 11 & MSc Education \\
\hline $\begin{array}{l}\text { - Highly specialised knowledge, } \\
\text { some of which is at the forefront } \\
\text { of knowledge in a field of work } \\
\text { or study, as the basis for original } \\
\text { thinking and/or research } \\
\text { - Critical awareness of knowledge } \\
\text { issues in a field and at the } \\
\text { interface between different fields } \\
\text { - Specialised problem-solving } \\
\text { skills required in research and/or } \\
\text { innovation in order to develop } \\
\text { new knowledge and procedures } \\
\text { and to integrate knowledge from } \\
\text { different fields }\end{array}$ & $\begin{array}{l}\text { - Demonstrate knowledge and } \\
\text { critical understanding of key, or } \\
\text { ideally all, of the main areas of } \\
\text { the subject/discipline/sector - } \\
\text { including their features, } \\
\text { boundaries, terminology, } \\
\text { conventions, principal theories, } \\
\text { concepts and principles. } \\
\text { - Practice: apply knowledge by } \\
\text { drawing on specialised skills, } \\
\text { techniques, practices and/or } \\
\text { materials which are at the } \\
\text { forefront in field to plan and } \\
\text { execute significant project or } \\
\text { research. } \\
\text { - Generic cognitive skills: mainly } \\
\text { critical analysis and synthesis to } \\
\text { key issues at the forefront, and } \\
\text { complex issue awareness. To } \\
\text { develop and conceptualise new } \\
\text { and abstract problems. } \\
\text { - ICT and Numeracy skills to } \\
\text { critically evaluate numerical and } \\
\text { graphical data. } \\
\text { Working with others: conduct } \\
\text { critical self-reflection, and others } \\
\text { roles and responsibilities }\end{array}$ & $\begin{array}{l}\text { The objectives of the programme } \\
\text { are to: } \\
\text { - develop students' understanding } \\
\text { of educational discourses and } \\
\text { issues } \\
\text { - critically evaluate research } \\
\text { publications } \\
\text { - develop key research skills and } \\
\text { transferrable skills } \\
\text { - equip students to investigate } \\
\text { and critically engage with } \\
\text { education research, policy and } \\
\text { practice }\end{array}$ \\
\hline
\end{tabular}

Unavoidable differences between education systems can be alleviated by having a national, regional, and international qualifications framework. A qualifications framework is 'an instrument for classifying qualifications according to a set of criteria for levels of learning outcomes achieved', and a National qualification framework will amongst other benefits facilitate student mobility within a country and/or internationally (Burke et al., 2009). This is of course under the assumption that there is agreement among different national and international education jurisdictions on measures for ascertaining quality, and recognition of quality standards. By mutual consent, in EU countries, the European Qualification Framework (EQF), and the European Higher Education Area (FQ-EHEA) also known as the Bologna Framework, facilitate transfer of credit obtained from member countries, and from which national frameworks such as the Scottish Credit and Qualifications Framework (SCQF) is drawn. Such frameworks are not common in Asia-Pacific countries. For example, Asia-Pacific Economic Cooperation (APEC) has 21 member economies, with seven countries that have developed NQFs (those being, as of 2009; Australia, Hong Kong SAR, China, Malaysia, New Zealand, Singapore, Thailand, and the Philippines; Burke et al. 2009). Concerted efforts are being made to internationalise the Hong Kong Qualification Framework (HKQF). To this end, in November 2014, The Hong Kong Qualifications Framework (HKQF) Conference on Qualifications across Boundaries: Perspectives of Hong Kong Qualifications Framework and European Qualifications Framework was held. At such early stages the outcome of the drive to integrate elements of the HKQF and the EQF and its applicability would likely require much consultation and review. This means that shifts from a 'traditional approach which emphasises learning inputs such as the length of a learning experience, or type of institution', as espoused by the EQF (EC 2009), is not an option that can be used to assess the prior learning outcome of many international students who come from countries without NQFs.

Notably, some APEC economies do not have an NQF. Within the USA federal system, state powers control education and there is little inclination towards developing a 'binding' NQF (Burke et al., 2009). With highly ranked institutions and globally recognised higher education system in the USA, perhaps there is also no evident need to 
develop an NQF for the purposes of quality assurance and credit transfer. For another APEC country, China, there are major differences between its education system and the Western education systems (O'Sullivan \& Guo, 2010). This means that in an ideal world, a NQF will be helpful to ascertain student prior learning to ease transitions from Chinese institutions to UK HEIs. This, however, is not currently the case.

Little is known about the adjustment of international students to specific aspect of learning in the UK; at Masters-level in general, and to developing critical thinking skills specifically. This is surprising considering the huge backdrop of literature which explicates the difficulty for Chinese students' to adapt to the Western learning culture of critical argumentation (Atkinson, 1997; Durkin, 2008; Hofstede, 2001; Nield, 2008; O’Sullivan \& Guo, 2010; Tian \& Low, 2011). The concept of critical thinking, and how this relates to Chinese students will be explored as backdrop for the study.

\subsection{Concept of Critical Thinking}

Critical thinking is a contested educational concept (Lai, 2011). There is no consensus on its definition, little agreement on its explicit meaning and differing perspectives on how it can be taught to students. But it is generally accepted to be a desired trait in higher education students (Barnett, 1997; Moon, 2008; Moore, 2013) and its importance is recognised by authors in different fields of education including, Philosophy (Facione, 1990), Psychology (Sternberg, Roediger III, \& Halpern, 2007) and adult education (Brookfield, 1987). The debate on defining critical thinking remains largely philosophical (Garrison, 1991) and to some extent is influenced by theoretical positions on the best pedagogical approaches to employ to develop students' critical abilities. It has also been suggested that critical thinking varies by discipline (Lai, 2011). In this brief overview, there will be an attempt not to prioritise a particular philosophical perspective of what critical thinking is conceived to be in particular disciplines. Rather, critical thinking can be considered to be "reasoning, inferring, and evaluating arguments" (Floyd, 2011, p. 291) to support or challenge what is presented as knowledge in academic matters (Davies, 2011; Cottrell, 2008).

There are two main opposing perspectives on how critical thinking can be taught to students; on a generic course (see Ennis, 1990), or discipline specific (McPeck, 1990). Robinson (2011) contends that extensive generalist conceptualisation in the literature and study guides justifies teaching critical thinking on a generic course. However, some authors argue that critical thinking can only be taught within the specific context of a discipline (Elander et al., 2006). Barnett (1997) and Brookfield (2005) add depth to the discourse by suggesting that the issue should not be how critical thinking is taught, but rather how higher education ought to equip students to become 'critical beings'. Students as critical beings should then critique ways of knowing within the larger society rather than focusing on developing critical thinking as an intellectual disciplinary exercise. But then the issue of how to help students become critical beings remains.

\subsection{Perspectives on the Critical Thinking Abilities of Chinese Students}

Durkin (2008) drawing on Hofstede (2001) argues that it is difficult for Chinese students' to adapt to the Western culture of critical argumentation in a UK university. Hofstede (2001) had written on how Confucian collectivist culture seeks to maintain societal harmony and authority, usually exemplified by high power distance between tutors and students. This is in contrast to Western individualistic culture which values criticality, argumentation, and as a result; low power distance between tutors and students. The effect of culture on the critical thinking disposition of Chinese students is typically attributed to the learning system in China which is widely reported to not encourage critical thinking and argumentation (O'Sulivan \& Guo, 2010). This perspective is countered by arguments that critical thinking (or the lack of it) of Chinese students cannot be solely attributed to Chinese culture (Shi, 2006; Tian \& Low, 2011). From studying 400 Chinese middle school students in China, Shi (2006) argues that the educational context in China is changing and there is insufficient understanding of Confucianism in the modern day to wholly attribute the learning disposition of Chinese students to their Confucian heritage - a view corroborated by Tian and Low (2011) who examined Chinese literature, and conclude that elements of reflective thinking, open mindedness and critical thinking can be found in Confucianism.

Wang (2013) further stresses that the emerging characteristics of Chinese learners can be seen as a fusion of their cultural heritage and Western influences on education at home and abroad. Shi and Wang's arguments are bolstered by empirical evidence demonstrating that Chinese students can learn successfully in the West (Gieve \& Clark, 2005; Kingston \& Forland, 2008). It should be noted though that assessments of Chinese students learning in the West mainly look at academic outcomes, i.e., whether they did well (ibid), or not (Ianelli \& Huang, 2013), but not their process of learning. Despite growing awareness that there are pedagogical implications of having diverse participants in Western higher education including international students (Kreber, 2009) it is not apparent from the literature how 
Chinese students develop critical thinking during their studies in the West.

\subsection{Developing Critical Thinking}

There is limited literature on specific steps to develop critical thinking despite general agreement that it can be taught (Lai, 2011). This means that it may be useful to consider Brookfield's widely cited notion on developing critical thinking in the field of adult education. Brookfield (1987) identifies five development phases of critical thinking in adults which is precipitated by a 'trigger event' - an occurrence which creates a sense of disquiet about current mode of thinking. This is then followed by an "appraisal of oneself, an exploration of new ideas and concepts, which then helps in developing alternative thinking, and finally, integrating the new way of thinking into daily living" (pp. 26-27). Though Brookfield's notions on developing critical thinking did not emanate out of a scientific investigation (Garrison, 1991), more vigorous empirical research on the subject in the fields of philosophy and Psychology (Sternberg, 1986) has not yet yielded conclusive evidence on exactly how critical thinking is developed over time (Facione, 1990; Lai, 2011). Suffice to say, 'basic' cognitive critical thinking as explicated in NQFs is a desired outcome of Masters-level study. A qualitative enquiry to obtain a deep understanding of this largely unexplored area is deemed to be valuable. This is particularly important when the learning occurs during a short period of time such as the one year duration of a Master's Programme in the UK in comparison with the two year Masters which are 'the norm' in many countries.

\section{Methodology}

This research set out to explore in depth the perceptions of Chinese students on how they develop critical thinking during a one year Masters-level programme in Scotland. As noted above Masters level study in the UK requires learners to engage critically with substantive content and present balanced arguments (Judge, Jones, \& McCreery, 2013) which is in keeping with the above mentioned SCQF levels. Empirical data were collected towards the end of students study time as we were interested in their reflections on the way in which their critical thinking had developed through the year. Participant profiles are shown in Table 2.

Table 2. Profile of Interview Participants

\begin{tabular}{|c|c|c|c|c|c|c|c|}
\hline $\begin{array}{l}\text { Name } \\
\text { (pseudonym) }\end{array}$ & Age & Gender & $\begin{array}{c}\text { English } \\
\text { test }\end{array}$ & Score & $\begin{array}{c}\text { EAP } \\
\text { Awareness }\end{array}$ & $\begin{array}{l}\text { Educational background } \\
\text { (BA Honours) }\end{array}$ & Pre-MSc experience \\
\hline Qiao & 23 & Female & TOEFL & 100 & $\begin{array}{l}\text { yes, but } \\
\text { did not } \\
\text { enrol }\end{array}$ & English Education & $\begin{array}{l}\text { Recently finished First } \\
\text { degree in China }\end{array}$ \\
\hline Lan & 25 & Female & IELTS & 7 & No & English and German & $\begin{array}{l}\text { Recently finished First } \\
\text { degree in China }\end{array}$ \\
\hline Mei & 24 & Female & IELTS & 6.5 & No & Chinese Language & $\begin{array}{l}\text { Recently finished First } \\
\text { degree in China }\end{array}$ \\
\hline Yan & 25 & Female & IELTS & 7 & No & $\begin{array}{l}\text { Journalism and } \\
\text { communication }\end{array}$ & $\begin{array}{l}\text { Taught Chinese to secondary } \\
\text { school students in Thailand } \\
\text { for } 2 \text { years before MSc study } \\
\text { in Scotland }\end{array}$ \\
\hline Lixue & 23 & Female & IELTS & 6.5 & No & $\begin{array}{l}\text { Chinese Language and } \\
\text { literature }\end{array}$ & $\begin{array}{l}\text { Recently finished First } \\
\text { degree in China }\end{array}$ \\
\hline Chen & 27 & Male & IELTS & 7 & $\begin{array}{l}\text { yes, but } \\
\text { did not } \\
\text { enrol }\end{array}$ & Education & $\begin{array}{l}\text { Primary school teacher in } \\
\text { China for two and half years } \\
\text { before MSc studies in } \\
\text { Scotland }\end{array}$ \\
\hline
\end{tabular}

Two pilot interviews were conducted to refine the interview questions, evaluate the selection criteria such as language proficiency of participants, and estimate time duration of the interviews. Interviews were conducted in English - the researcher being non-Chinese. Cortazzi, Pilcher and Jin (2011) note that language choice (e.g., English) could affect the duration of interview and data collected from Chinese participants who need to articulate their thoughts in a second language. IELTS scores between 6.0 and 7.0 are required for entry to most universities in the UK (Brown, 2008; Edwards and Ran, 2006). In the case selected the minimum for entry of 6.5 was attained by all participants. All interviews lasted for approximately 30 minutes. 
Six Chinese students participated in the study comprising five females and one male from a variety of undergraduate backgrounds in China, and they were all studying in the UK for the first time (see Table 2). The age bracket of the participants (23 to 27 years) can be considered as a meaningful age category suggesting the likelihood of participants having similar 'life courses' (Bechhofer \& Paterson, 2000) including prior education in China. The skew towards a more female representation reflects the general population of students in the faculty. Convenience sampling was adopted to recruit from the ample number of Chinese nationals on the programme. The focus of this work was on developing a deeper understanding of experiences rather than on generalizability so qualitative work with a small number of participants was deemed to be an appropriate research design. The rich data collected from the six participants through in-depth semi-structured interviews provided deep insight into the challenges they faced during the one year masters, and crucially, their process of developing critical thinking - for which, as earlier discussed, much understanding is needed.

Table 3. Semi Structured Interview (Open Ended) Questions Used in This Research

Q1 What do you understand as critical thinking?

Q2 Has your understanding of critical thinking changed from before your studies in Scotland and now? If so, how?

Q3 How long do you think it took, and when did you begin to understand the importance of critical thinking for your studies?

Q4 How have you developed critical thinking during your MSc studies?

Q5 Can you describe what has helped you to develop critical thinking?

Data analysis started immediately following the first interview and involved an iterative and reflexive process (Stake, 1995). Open ended questions were used at the interviews to further probe interesting cues that developed during conversations. Interviews were audio recorded and data transcribed verbatim for further analysis. Using the constant comparison method of data analysis (Schutt, 2011) data were examined repeatedly to construct themes and categories. 'Extensive analysis' of key aspects of the unabridged data and 'intensive analysis' of common themes (Silverman, 2011) was useful in identifying interconnected themes and recurring patterns from raw data to form categories. Concerns about validity and reliability of qualitative research (Guba \& Lincoln, 2008) especially involving a small number of cases (Stake, 1995) are diminished by considering the aim of much qualitative research which is for an 'authentic understanding of peoples experiences (Silverman, 2011).

\section{Findings}

Findings from the research are reported in summary format by response to the open ended questions (see Table 3). Connections to previous research are detailed in the subsequent sections.

Q1 What do you understand as critical thinking? / If your understanding of critical thinking changed from before your studies in Scotland and now? How?

Prior to their studies in the UK, and during the first few months after starting their programme, all the participants describe how they perceive critical thinking as meaning that 'something is bad' and needs to be criticised:

I thought critical thinking means you must challenge the ideas of other people (Mei)

Before I came to do my Masters here (in Scotland), I have not heard a lot about critical thinking, so I just take it at the meaning of the word - critical - in my opinion, this means that you have to criticise something, list the disadvantages or the mistakes with some argument (Lan).

While participants described cursory awareness of critical thinking before coming to study in the UK, their first inkling of its importance for academic study was when they read about critical thinking in their programme handbook which was given to them during their induction program. Some participants (e.g., Yan, Lixue and Mei) said the words in the handbook informing them they were expected to critically engage on their coursework are 'just words' without a clear meaning. Notably, most of the participants had IELTS score 7.0 (see Table 2) which is "probably acceptable" for "linguistically demanding academic programmes" (IELTS handbook, 2007, p. 5). However, their English language proficiency did not seem to prevent their initial misconception of critical thinking or improve their understanding beyond the "words" to its meaning.

In preparation to study in Scotland, one participant (Mei) said she mainly focused on her English test to be able to 
enrol on the programme, but did not consider other academic requirements - as she was already a good student in China. Another participant (Qiao), who studied English education at undergraduate level in China said she had prepared for studying in the UK by reading many English novels. All, except Qiao, expressed their lack of awareness of just how important critical thinking is for academic success in the West. The participants conveyed a sense of disquiet and confusion in their new learning environment which is consistent with what Griffiths, Winstanley and Yiannis (2005) describe as learning shock. Some typical interjections during discussion include, "it is so different here" or "it's a big step". During the interview Yan, exasperatedly exclaimed:

They [tutors] just say critical, critical, critical! What do they mean?

Despite the emphasis by tutors on the importance of critical thinking, it is as if "talking a lot" about critical thinking in class did not seem to aid the participants' understanding of the concept. Lixue, who had passed the taught element of her programme, attributes her performance to luck rather than deep understanding. Most of the participants had also changed to study Education (see Table 2). Studying in a new country and a new academic discipline could account for some adjustments in coping with the demands of their course.

Though Chinese students are more often portrayed in literature as lacking critical thinking (Tian \& Low, 2011), Qiao and Lixue believed that they had been thinking critically in China. Lixue claimed to have had why questions before coming to the UK. This is coherent with observations that the higher educational system in China is changing with more Western influence (Wang, 2013). It is also possible that the participants had an innate questioning disposition which might not have been verbalised, in compliance with the norm in the academic environment in China as purported by Lixue and the other participants.

Q2 How long do you think it took for you to develop critical thinking?

All the participants' articulated the gradual process of developing critical thinking. This ranged from two months (during the first semester) to four months (start of the second semester). Many have argued that critical thinking is discipline specific. It might be important to note that Chen is the only participant with an undergraduate Education background, and of all the participants, he said he 'got it' after two months. He also attributes 'high marks' on his assignments as evidence of his understanding. All other participants talked more about their struggles and how they started to develop a better understanding of critical thinking after 3 to 4 months.

\section{Q3 When did you begin to understand the importance of critical thinking?}

The first semester assignment feedback was a pivotal source of awareness and motivation to develop critical thinking, with Lan stating that "Feedback is important because you know what you lack". Mei also said:

I thought critical thinking was simple - just give the opposite opinion. I really got low marks on my first semester assignment, so I started thinking - what is missing? What do the teachers want? This was when I knew that critical thinking was important.

Self-appraisal of the participants' critical thinking abilities chiefly resulted from their first semester coursework feedback. This varied among the participants from relative confidence in their critical thinking abilities (Chen \& Qiao) to deep uncertainty about their progress (Yan, Mei \& Lixue). It was apparent that the participants went through a disquieting period that could be seen as a trigger to find ways to develop critical thinking for academic success.

\section{Q4 Can you describe what has helped you to develop critical thinking?}

Some participants said that reading books on developing critical thinking and study skills books for international postgraduate students (e.g., Davies, 2011; Wallace \& Wray, 2006) was helpful. Additionally, reading recommended journal articles was a good starting point which helped them to develop their critical thinking.

When I read a journal, I also look at the references, from this I get totally different ideas from other authors, so I ask myself a lot of questions. I will try to find which author I agree more with and why I agree more with that viewpoint (Yan).

Three of the interviewees (Qiao, Lan and Mei) attended a course on Critical Reading for Self-Critical Writing during the second semester. The aim of the course/workshop was to give students the opportunity to 'experiment with the techniques' of critical reading and writing. Apart from attending the seminar, Mei also checked online resources on academic writing and critical thinking which were available from the university. It was beneficial for students to draw upon available resources within the academic environment to develop critical thinking.

Help from tutors

Tutors can help to nurture critical thinking in students (Brookfield, 1987; Moon, 2008). Personal tutors in the 
research setting give academic and pastoral support to students who are assigned to them. This was valued by the participants and some cite instances when their personal tutors helped:

During our first meeting I asked my personal tutor what critical thinking is and he gave me a list of what I should look for in an article. I think his advice was very helpful to help me look more deeply in articles (Lan).

Class discussion

Most courses require students to do some reading before attending a lecture or seminar to discuss both the lecture and the readings. This was a new learning approach to the participants and they all expressed their struggle with this aspect of their studies. However, as they are used to complying with tutors' directives, they made attempts to read the assigned papers. Some participants said they gradually began to express their views in class. Interestingly, references were made to Chinese students who just "talk in class without deep thinking" (Mei), and "Western students who do not listen but talk too much" (Yan). It appears that the context of the class discussions helped the participants to articulate their own critical perspective of valid or superfluous viewpoints expressed by their peers.

Writing assignments

One participant, Lan, said "critical writing is a key aspect of critical thinking" and she narrated her process of evaluating the viewpoints of other authors before developing her own opinion in attempts to reflect a critical perspective in her coursework:

I think to develop critical thinking is in two ways, one is to develop [critical] reading - that's like an input. Another thing is to develop your [critical] writing and that's the output. Its only when you grasp the two aspects of critical thinking, then you can grasp the skill of critical thinking

Joining social groups

Some students gave examples of social interactions within the university community, such as visiting the International Café, and joining International Buddies*. When Chen was further questioned on how his social interaction at the International Café helped him develop critical thinking, he gave a detailed explanation:

I don't go to events to develop my critical thinking but when I recall the events at the international café I realised that it was helpful for developing my critical thinking I learnt how to think about things instead of showing off what I had memorised. In my academic work, I will gradually delete all the parts describing and add some of the parts thinking and add some of the parts quoting from others to make a good argument for the paper. This was a really good idea.

\section{Discussion}

The discourse on the lack of critical thinking of Chinese students due to their learning culture (Atkinson, 1997) is not the object of this study, but rather perceptions of the study participants on their process of developing critical thinking in a different cultural context and learning environment. Early on during their studies, participants needed to understand the concept of critical thinking, and its importance for a successful academic outcome. This resonates with perceptions that tertiary-level Chinese students in the UK struggle to adjust to the academic requirement at the initial stages of their studies in the UK (Brown, 2008; Gill, 2007). It is interesting that, without prompting, the Chinese study participants gave comments which suggest that they believe critical thinking requires deep learning rather than superficial learning - a point that is often emphasised in the literature on critical thinking. Getting to that point of critical self-evaluation was a gradual process with differing learning curves.

A positive or negative event could be the trigger to develop critical thinking (Brookfield, 1987). For five of the six participants, receiving their feedback was a negative event because they felt they were 'good' students in China and could have performed better. On the contrary, the course feedback was a positive experience for Chen. This could however not be described as a "positive trigger" to develop critical thinking. Chen described a gradual period of time before he "suddenly" understood critical thinking. Importantly this occurred before submitting his assignment, and he could integrate his understanding sufficiently to attain A's on his first semester coursework. The different process of developing critical thinking by the participants further highlights what Facione (1990), and Garrison (1991) describe as the complexity of understanding how critical thinking develops as a process.

Other than the complexity of the subject of developing critical thinking, the small number of participants in the study may not be considered as representative. As in much qualitative research which aims for an 'authentic understanding' of peoples experiences (Silverman, 2011), and with increasing interest to explore the emerging characteristics of 
Chinese learners (Wang, 2013), the study should be seen as explorative and providing contextual understanding of the lived experience of the participants and how they perceive they develop critical thinking.

While the participants struggled with the academic demands of their programme - mostly at the onset of their studies, they expressed willingness to adapt and develop critical thinking in their academic context in the UK - and even thereafter use their understanding when they went back to their country. Yan understood the concept of critical thinking to say that:

Before, I thought critical thinking means that your ideas are different from others. Now what matters is that your ideas come out of deep thought. You must think of the ideas of others too and make a reasoned judgement

\section{Conclusion}

All higher education students in Western countries are expected to display critical thinking as an explicit course requirement. Studying in a different learning and cultural environment in Scotland allowed the participants to explore a different way of learning - 'from memorisation to reflection and reasoned argument' (Chen).

Coursework feedback can be considered as a 'trigger event' for the participants to appraise and develop their critical thinking. Reading books and journal articles proved useful during this development process. Reading articles before lectures encourages interaction in class and can contribute to developing critical thinking.

Opportunities to have multicultural interactions during classes, with flatmates, and during social events were helpful for some of the participants in practicing and developing critical thinking. But students do not normally choose their flatmates in allocated university accommodation. There may thus be a case for promoting mixing students from different countries in university housing provision. However, social activities or clubs may not guarantee such discussions as individual attributes may influence participation and engagement.

All above mentioned attempts by students to develop critical thinking requires pedagogic support. To this end, a binary conception of pedagogy for critical thinking may be unhelpful. Rather, a general and specific approach to teaching critical thinking might be beneficial for host institutions who need to provide support for specific academic requirements that may be unfamiliar to Chinese students. The timing of such support is also important. For one participant (Mei), her attempt to develop critical thinking is described below:

After I realised that critical thinking was important, every time I read an article I will try to force myself to think about something different, not just to trust all the information, when I have a question, I will write it down or make notes or sometimes when I get to the class I will ask the teacher about my question.

Unfortunately for Mei, her first semester grades were too low to progress to dissertation and complete her MSc. Mei is not alone. Her experience is consistent with empirical work on progression and completion of first degrees by Chinese students in the UK (Iannelli \& Huang, 2013). The stigma and finality attached to failure with assessment methods below doctoral level (McArthur, 2014), and visa conditions in the UK whereby non-EU international students may not normally re-enrol on the same Masters programme, means that for Mei, completing an MSc in the UK is unlikely to happen. To end on a positive note, all other participants in the study achieved the MSc and testified to the benefit of having access to the many resources available within their study environment - but they needed guidance to understand the concept of critical thinking and to integrate it into their own work.

\section{Further Research}

The key aim of this study is to understand students' perceptions of the process of developing critical thinking for academic purposes after the initial shock of facing an unaccustomed learning style. Currently, pre-sessional courses such as English for Academic Purposes (EAP) is designed to help international students improve generic academic abilities in preparation for studying in the UK but it is mainly focused on supporting students with low English test scores. As it is unlikely that a global qualification framework can be developed, and considering the wide use of the English language test, it is beneficial to assess critical thinking before student enrol on their designated programme. Critical Thinking for Academic Purposes (CTAP) could be designed as an introductory course for postgraduate students. CTAP is conceived as a formative assessment. The course feedback is expected to be an important trigger to signpost students to the expected level of critical thinking on their courses. Determining the pedagogic approach and qualifying students on the course (CTAP), requires further research into the prior learning context of a broader range of students - which may perhaps include home students. 


\section{References}

Atkinson, D. (1997). A critical approach to critical thinking in TESOL. TESOL Quarterly, 31, 71-94. http://dx.doi.org/10.2307/3587975

Barnett, R. (1997). Higher education: A critical business. Buckingham: SRHE/Open University Press.

Bayliss, A., \& Ingram, D. E. (2006). IELTS as a predictor of academic language performance. Australian International Education Conference. Perth, Australia.

Bechhofer, F., \& Paterson, L. (2000). Principles of research design in the social sciences. London: Routledge.

British Council. (2014). UK-China higher education roundtable. Beijing, China: British Council.

Brookfield, S. D. (1987). Developing critical thinkers: Challenging adults to explore alternative ways of thinking and acting. London: Jossey-Bass.

Brookfield, S. D. (2005). The power of critical theory for adult learning and teaching. England: Open University Press.

Brown, L. (2008). The incidence of study-related stress in international students in the initial stage of the international sojourn. Journal of Studies in International Education, 12, 5-28. http://dx.doi.org/10.1177/1028315306291587

Burke, G., Keating, J., Vickers, A., Fearnside, R., \& Bateman, A. (2009). Mapping qualifications frameworks across APEC economies. Report: APEC Secretariat, Singapore.

Business, Innovation and Skills (BIS) (2011). UK and China embark on education partnership. Retrieved from https://www.gov.uk/government/news/uk-and-china-embark- on-education-partnership-208November 2014

Cortazzi, M., Pilcher, N., \& Jin, L. (2011). Language choices and 'blind shadows': Investigating interviews with Chinese participants. Qualitative Research, 11, 505-535. http://dx.doi.org/10.1177/1468794111413225

Cottrell, S. (2008). The study skills handbook. Hampshire: Palgrave Macmillian.

Davies, M. (2011). Study skills for international postgraduate students. London: Palgrave Macmillan.

Durkin, K. (2008). The adaptation of East Asian masters students to western norms of critical thinking and argumentation in the UK. Intercultural Education, 19, 15-27. http://dx.doi.org/10.1080/14675980701852228

Edwards, V., \& Ran, A. (2006). Meeting the needs of Chinese students in British higher education. Research paper. Reading: University of Reading.

Elander, J., Harrington, K., Norton, L., Robinson, H., \& Reddy, P. (2006). Complex skills and academic writing: A review of evidence about the types of learning required to meet core assessment criteria. Assessment and Evaluation in Higher Education, 31, 71-90. http://dx.doi.org/10.1080/02602930500262379

Ennis, R. H. (1990). The extent to which critical thinking is subject specific: Further clarification. Educational Researcher, 19, 13-16. http://dx.doi.org/10.3102/0013189X019004013

European Commission (2009). The Bologna Process, Towards the European Higher education area. Retrieved from $\mathrm{http} / / /$ ec.europa.eu/education/policy/higher-education/bologna-process_en.htm

European Qualification Framework (EQF) Descriptors defining levels in the EQF. http://ec.europa.eu/ploteus/en/content/descriptors-page

Facione, P.A. (1990). Critical thinking: A statement of expert consensus for purposes of educational assessment and instruction. Executive Summary "The Delphi Report”. Millbrae, CA: California Academic Press.

Floyd, C. B. (2011). Critical thinking in a second language. Higher Education Research and Development, 30 , 289-302. http://dx.doi.org/10.1080/07294360.2010.501076

Garrison, D. R. (1991). Critical thinking and adult education: A conceptual model for developing critical thinking in adult learners. International Journal of Lifelong Education, 10, 287-303. http://dx.doi.org/10.1080/0260137910100403

Gieve, S., \& Clark, R. (2005). The Chinese approach to learning: Cultural trait or situated response? The case of a self-directed learning programme. System, 33, 261-276. http://dx.doi.org/10.1016/j.system.2004.09.015

Gill, S. (2007). Overseas students' intercultural adaptation as intercultural learning: A transformative framework. Compare: A Journal of Comparative and International Education, 37, 167-183. 
http://dx.doi.org/10.1080/03057920601165512

Griffiths, D. S., Winstanley, D., \& Yiannis, G. (2005). Learning shock: The trauma of return to formal learning. Management Learning, 36, 275-297. http://dx.doi.org/10.1177/1350507605055347

Guba, E.G., \& Lincoln, Y.S. (2008). Paradigmatic controversies, contradictions, and emerging confluences. In N. K. Denzin Y. S. Lincoln (Eds.) The landscape of qualitative research (pp. 255-286). London: Sage.

HESA (2015). Higher education student enrolments and qualifications obtained at higher education providers in the United Kingdom. Retrieved from https://www.hesa.ac.uk/sfr210

Hofstede, G. (2001). Culture's consequences: Comparing values, behaviours, institutions and organisations across nations. London: Sage.

Hong Kong Qualification Framework (HKQF) (n.d.). Generic level descriptors. Retrieved from http://www.hkqf.gov.hk/guie/home.asp

Ianelli, C., \& Huang, J. (2013). Trends in participation and attainment of Chinese students in UK higher education. Studies in Higher Education, 39, 805-822. http://dx.doi.org/10.1080/03075079.2012.754863

IELTS (2007). International English language testing system handbook. London: British Council.

Judge, B., Jones, P., \& McCreery, E. (2013). Critical thinking skills for education students. London: Learning Matters.

Kingston, E., \& Forland, H. (2008). Bridging the gap in expectations between international students and academic staff. Journal of Studies in International Education, 12, 204-221. http://dx.doi.org/10.1177/1028315307307654

Kreber, C. (2009). Supporting student learning in the context of diversity, complexity and uncertainty. C. Kreber (Ed) The university and its disciplines: Teaching and learning within and beyond disciplinary boundaries (pp. 3-18). London: Routledge.

Lai, E. R. (2011). Critical thinking: A literature review. Research Report: Pearson.

McArthur, J. (2014). The learning-feedback-assessment triumvirate: Reconsidering failure in the pursuit of social justice. In C. Kreber, C. Anderson, N. Entwistle, \& J. McArthur (Eds.), Advances and Innovations in University Assessment and Feedback (pp. 173-196). Edinburgh: Edinburgh University Press. http://dx.doi.org/10.3366/edinburgh/9780748694549.003.0010

McPeck, J. E. (1990). Critical thinking and subject specificity: A reply to Ennis. Educational Researcher, 19, 10-13. http://dx.doi.org/10.3102/0013189X019004010

Moon, J. (2008). Critical thinking: An exploration of theory and practice. London: Routledge.

Moore, T. (2013). Critical thinking: Seven definitions in search of a concept. Studies in Higher Education, 38, 506-522. http://dx.doi.org/10.1080/03075079.2011.586995

Moray House School of Education. MSc Education Handbook for Students 2012/2013. Edinburgh.

Nield, K. (2008). Understanding the Chinese learner: A case study exploration of the notion of the Hong Kong Chinese learner as a rote or strategic Learner. Journal of Hospitality, Leisure, Sport and Tourism Education, 6, 39-48. http://dx.doi.org/10.3794/johlste.61.131

O'Sullivan, M., \& Guo, L. (2010). Critical thinking and Chinese international students: An East-West dialogue. Journal of Contemporary Issues in Education, 5, 53-73.

Robinson, S. R. (2011). Teaching logic and teaching critical thinking: Revisiting McPeck. Higher Education Research and Development, 30, 275-287. http://dx.doi.org/10.1080/07294360.2010.500656

Schutt, R. K. (2011). Investigating the social world: The process and practice of research. London: Sage.

Schweisfurth, M., \& Gu, Q. (2009). Exploring the experiences of international students in UK higher education: Possibilities and limits of interculturality in university life. Intercultural Education, 20, 463-473.

Scottish Credit and Qualifications Framework (2010). SCQF level descriptors. Retrieved from www.scqf.org.uk/content/files/SCQF_Level_Descriptors_for_website_-Feb_2010(2).pdf

Scottish Government (2012). Working with China: A five year strategy for engagement between Scotland and the People's Republic of China. Retrieved from http://www.scotland.gov.uk/Resource/0040/00409256.pdf

Shi, L. (2006). The successors to Confucianism or a new generation? A questionnaire study on Chinese students' 
culture of learning English. Language, Culture and Curriculum, 19, 122-147. http://dx.doi.org/10.1080/07908310608668758

Silverman, D. (2011). Interpreting qualitative data: A guide to the principles of qualitative research. London: Sage.

Spencer-Oatey, H., \& Xiong, Z. (2006). Chinese students' psychological and sociocultural adjustments to Britain: An empirical study. Language, Culture and Curriculum, 19, 37-53. http://dx.doi.org/10.1080/07908310608668753

Stake, R. (1995). The art of case study research. London: Sage.

Sternberg, R. J. (1986). Critical thinking: Its nature, measurement, and improvement. Washington, DC: National Institute of Education. Retrieved from http://eric.ed.gov/PDFS/ED272882.pdf

Sternberg, R. J., Roediger III, H. L., \& Halpern, D. F. (Eds.) (2007). Critical Thinking in Psychology. New York: Cambridge Univ. Press.

Tian, J., \& Low, G. D. (2011). Critical thinking and Chinese university students: A review of the evidence. Language, Culture and Curriculum, 24, 61-76. http://dx.doi.org/10.1080/07908318.2010.546400

Wallace, M., \& Wray, A. (2006). Critical reading and writing for postgraduates. London: Sage.

Wang, J. (2013). Constant and emerging characteristics of Chinese learners in changing school contexts. Journal of Curriculum Studies, 42, 277-293. http://dx.doi.org/10.1080/00220272.2012.739801

Wu, W., \& Hammond, M. (2011). Challenges of university adjustment in the UK: A study of East Asian masters' degree students. Journal of Further and Higher Education, 35, 423-438. http://dx.doi.org/10.1080/0309877X.2011.569016

Zhou, Y., \& Todman, J. (2009). Patterns of adaptation of Chinese postgraduate students in the United Kingdom. Journal of Studies in International Education, 13, 467-486. http://dx.doi.org/10.1177/1028315308317937 